\title{
Nilai-nilai Pendidikan Agama Islam dalam Q.S. Luqman ayat 12-19 telaah Tafsir Al-Azhaar dan Al-Misbah
}

\author{
*Kifayatul Akhyar, Junaidi, Zulfani Sesmiarni, Supratman Zakir \\ Institut Agama Islam Negeri (IAIN) Bukittinggi
}

\author{
*E-mail: Kifayatulakhyar2507@gmail.com
}

\author{
Receive: 13/05/2021 \\ Accepted: 23/08/2021 \\ Published: 01/10/2021
}

\begin{abstract}
Abstrak
Latar belakang masalah pada penelitian ini mengangkat nilai-nilai pendidikan Islam yang terkandung dalam Q.S Luqman ayat 12-19 yang merupakan pedoman bagi manusia yang di jadikan fondasi dan dasar untuk mendidik manusia ke jalan yang benar. Sedangkan fokus peelitian ini adalah nilai pendidika Islam yang terdapat dalam surat Luqman ayat 12-19. Nilai pendidikan Islam tersebut kemudian dilihat apa saja janji serta ancaman Allah Swt (al-wa'du dan al-waid). Penelitian ini bertujuan untuk melihat dan menggambarkan lebih dalam terkait nilai pendidikan Islam serta janji dan ancaman Allah SWT ( $a l$-wa'du dan al-wa'id) yang terdapat dalam surat Luqman ayat 12-19. Rumusan masalah dalam penelitian ini adalah nilai-nilai pendidikan Islam yang terkandung dalam surat Luqman ayat 12-19. Nilai tentang pendidikan Islam dalam Q.S Luqman ayat 12-19 yang ada kaitannya dengan janji Allah SWT (al-wa'du). Serta nilai pendidikan Islam dalam surat Luqman ayat 12-19 yang berkaitan dengan ancaman Allah SWT (al$w a^{\prime} i d$ ).Adapun metode yang digunakan pada penelitian ini menggunakan penelitian kepustakaan (library research), karena data yang diteliti berupa Al-Qur'an dan terjemahannya, tafsir, jurnal, dokumen-dokumen, buku-buku, artikel, maupun literatur-literatur yang bersumber dari perpustakaan. Setelah ditelaah kemudian data yang didapatkan dengan memanfaatkan metode dokumentasi yang di ambil dalam Al-Qur'an. Kitab-kitab tafsir yang mu'tabar dijadikan suatu referensi yang utama bagi peneliti untuk menafsirkan suatu dari makna ayat. Kemudian data dianalisis dengan kaedah yang komparatif, deduktif dan induktif. kemudian terkait metode tafsir digunakan metode tafsir tahlili.Hasil dari penelitian menunjukan, (1) nilai dari pendidikan Islam dalam Q.S Luqman ayat 12-19 diantaranya terdapat tiga perspektif, yaitu pendidikan aqidah, syariah, akhlak. Pendidikan dari aqidah menjelaskan tentang bahaya syirik (menyekutukan Allah SWT), pendidikan syria'ah perintah mendirikan sholat dan amal ma'ruf nahi munkar dan pendidikan akhlak perintah berbuat baik kepada kedua orang tua dan larangan berbuat sombong. (2) Nilai-nilai pendidikan Islam tersebut kemudian di lihat apa saja janji Allah SWT ( $a l-w a^{\prime} d u$ ) jika diterapkan dengan baik dan benar maka janji Allah akan dibalasi dengan pahala dan syurga. (3) kemudian nilai-nilai pendidikan Islam tersebut dilihat apa saja anacaman Allah SWT (al-wa'id), jika seseorang melanggar maka ancaman Allah seseorang tersebut akan dimasukan ke dalam neraka Kata Kunci: Media Pembelajaran, Pohon Aksara, Hasil Belajar.
\end{abstract}

Kata kunci: Nilai, Pendidikan Islam, Al-Wa'du dan Al-Wa'id

\begin{abstract}
The background of the problem in this study raises the values of Islamic education contained in Q.S Luqman verses 12-19 which is a guide for humans that is used as the foundation and basis for educating humans to the right path. While the focus of this research is the value of Islamic education contained in the letter Luqman verses 12-19. The value of Islamic education is then seen what are the promises and threats of Allah SWT (al-wa'du and al-waid). This study aims to see and describe more deeply the value of Islamic education and the promises and threats of Allah SWT (al-wa'du and al-wa'id) contained in the letter Luqman verses 12-19. The formulation of the problem in this study is the values of Islamic education contained in the letter Luqman verses 12-19. The value of Islamic education in Q.S Luqman verses 12-19 which has to do with the promise of Allah SWT (al-wa'du). As well as the value of Islamic education in the letter Luqman verses 12-19 relating to the threat of Allah SWT (al-wa'id). The method used in this study uses library research, because the data studied are in the form of the Qur'an. and their translations, interpretations, journals, documents, books, articles, and literature sourced from the library. After reviewing the data obtained by utilizing the documentation method taken in the Qur'an. The books of interpretation that are mu'tabar are used as the main reference for researchers to interpret the meaning of the verse. Then the data were analyzed using comparative, deductive and inductive methods. then related to the interpretation method, the tahlili interpretation method is used. The results of the study show, (1) the value of Islamic education in Q.S Luqman verses 12-19 of which there are three perspectives, namely aqidah, sharia, and moral education. Education from aqidah explains the dangers of shirk (associating partners with Allah SWT), syria'ah education commands to establish prayer and good deeds nahi munkar and moral education commands to do good to both parents and prohibits being arrogant. (2) The values of Islamic education are then seen what are the promises of Allah SWT (al-wa'du) if implemented properly and correctly then Allah's promises will be rewarded with rewards and heaven. (3) then the values of Islamic education are seen what are the threats of Allah SWT (al-wa'id), if someone violates the threat of Allah that person will be put in hell.
\end{abstract}


Jurnal Edumaspul, 5 (2), Year 2021- 752

(Kifayatul Akhyar, Junaidi, Zulfani Sesmiarni, Supratman Zakir)

\section{Pendahuluan}

Agama adalah rahmat bagi sekalian umat manusia, ketika setiap pribadi manusia yang melaksanakan alktifitas sosialnya yang di dalam urusan sosialnya tersebut di dalam nya ada mengandung unsur-unsur dan nilai yang berkaitan dengan agama. Nilai-nilai di dalam Islam merupakan suatu dasar yang sangat penting apabila seseorang menjalankan nilai-nilai ke Islaman tersebut dengan benar dan sesuai syari'at, maka dengan demikian, orang tersebut akan terjaga dan terselamatkan dari ke fanaan dunia dan akhirat. Dan sebaliknya jika seseorang tersebut tidak menjalankan nilai-nilai yang ada di dalam agama kususnya agama di rahmati yakni Islam, maka orang tersebut telah berbuat suatu kedzaliman yang sangat besar dan orang tersebut telah mencampakkan dirinya kedalam kemaksiatan dan kedalam lembah kesyirikan. Perbuatan syirik merupakan suatu kedzaliman yang sangat besar dan merupakan salah satu dosa besar yang akan menenggelamkannya did alam kecelakan di dunia dan di akhirat akan mendapatkan azab yang sangat pedih.

Dalam kita memahami, mempelajari, mengamalkan serta megajarkan dan menanamkan nilai-nilai ke Islaman pada kehidupan sehari-sehari, tentunya sangat dibutuhkannya pengalaman, pembelajaran, pemahaman di dalam Pendidikan agama Islam yang diajarkan dan di terapakan dalam kehidupan sehari-hari. Nilai-nilai Pendidika Agama Islam sangat penting untuk di pahami. di pelajari dan diajarkan kepada anak didik, karena melalui penanaman nilai-nilai Islam maka di dalam jiwa pesrta didik tesebut akan tertanam aqidah, keimanan keyakinan serta kepercayaan yang kokoh. Maka dengan demikian akan muncul generasi-generasi penerus bangsa yang beriman dan bertaqwa kepada Allah SWT.

Faktanya pada hari ini Pendidikan Agama Islam masih mengalami krisis dalam menerapkan dan menanamkan nilai ke Islam pada anak didik. Hal tersebut dipengaruhi oleh ligkungan masyarakat yang masih memiliki minimnya ilmu keagamaan seperti masalah tahayul, kurafat, bid'ah bahkan ada kekufuran dan syirik. Kalam Allah yang sangat luar biasa tidak bisa dibandingkan dengan yang lain, bahkan sangat banyak hadis Rasulullah yang memberitahukan tentang keagungan dan kebenarannya. Dalam al-Qur'an sangat banyak terdapat kisah-kisah umat terdahulu dan menjadi pedoman bagi kita di masa sekarang, sangat banyak ayat yang memeritahkan kepada orang mukmin untuk menerapkan dan menhayati hukum-hukum Allah SWT. Al-Qur'an merupakan rujukan yang pertama dan paling utama bagi umat manusia terutama bagi orang mukmin di dalam pendidikan, karena hak itu merupakan fitrahnya sebagai makhluk Allah SWT diatas bumi.

Steeman mengungkapkan nilai merupakan suatu hal yang memberikan makna pada hidup, yang memberikan acuan, tolak ukur dan tujuan hidup. Nilai merupakan suatuhal yang dijunjung dengan tinggi yang dapat menjiawai serta mewarnai perbuatan seseorang. Nilai itu lebih dari keyakinan dan nilai akan menyangkut pada pola fikir serat tindakan, sehingga nilai dan etika sangat erat hubungannya antara sattu dengan yang lain.

Dalam surat Luqman ayat 12-19 ini terdapat nilai-nilai pendidikan Islam yang terdiri dari nilai pendidikan Aqidah, Syaria'ah dan Akhlak. Dalam penelitiaan ini nilai-nilai pendidikan Islam yang ada dalam surat Luqman ayat 12-19 dikaji apasaja janji dan ancaman Allah Swt (al-wa'id dan $a l-w a^{\prime} d u$ ) jika seseorang menerapkan dan melanggar dari setiap nilai pendidikan Islam yang terdiri dari tiga aspek yaitu nilai pendidikan Aqidah, Syaria'ah dan Akhlak dari ayat surat Luqman ayat 12-19. Dan di tafsirkan menurut pandangan para mufasir dari dua buah tafsir diantaranya tafsir Al-Azhar dan tafsir Al-Mishbah. Untuk mengetahui hal tersebut, penulis ingin mengkaji lebih dalam pemaparan mengenai nilai dari pendidikan Islam yang terdapat dalam surat Luqman ayat 12-19 serat janji dan ancaman Allah (al-wa'id dan al-wa'du). Penelitian dalam tesis ini merupakan penelitian kepustakaan (library research) dengan judul

\section{Metode}

Jenis penelitian yang penulis gunakan dalam penelitian ini adalah studi pustaka (library research). Menurut Mestika zed dalam bukunya Metode Kepenilitian Kepustakaan, studi kepustakaan adalah serangkaian kegiatan yang berkenaan dengan metode pengumpulan data perpustakaan, membaca, dan mencatat serta mengolah bahan penelitian.13Karena penelitian ini merupakan library research, maka sumber data pada penelitian ini adalah literatur atau sumber yang berkaitan dengan pembahasan.

Metode yang di gunakan adalah library research, yaitu penelitian kajian pustaka. Peneletian kepustakaan ini bertujuan untuk mengumpulkan informasi data dengan sumber yang terdapat dalam khazanah pustaka. Penelitian ini bersifat 
Jurnal Edumaspul, 5 (2), Year 2021- 753

(Kifayatul Akhyar, Junaidi, Zulfani Sesmiarni, Supratman Zakir)

deskriptif analisis, yaitu mengkaji permasalahan secara mendalam dengan mengemukakan analisaanalisa dan menggambarkan secara rinci terhadap permasalahan yang di teliti. Untuk itu, karena penelitian ini berkaitan dengan penelitian terhadap ayat al-Qur'an yaitu surat Luqman.

\section{Hasil dan Pembahasan}

\section{a. Tafsir Al-Azhar}

Dalam ayat ke-12 dijelaskan bahwasanya Luqman mendapat hikmat dari Allah sesudah ayat 11 di terangkan, bahwa orang-orang yang zhalim senantiasa dalam kesesatan yang nyata. Sekarang datang ayat ke-12 ini yang menerangkan bahwa Allah telah mengaruniakan hikmat. Sebab itu Luqman terlepas dari kesesatan yang nyata. Arrazi telah menerangkan dalam tafsirnya bahwa hikmat itu ialah "Sesuai di antara perbuatan dengan pengetahuan".

Maka setiap orang yang di berikan taufiq oleh Allah Swt, tentu akan sesuai perbuatan dengan pengetahuannya, amalannya dengan ilmunya, hal tersebut merupakan orang yang mendapatkan karunia hikmat dari Allah SWT. Tetapi jika ada orang yang bersungguh-sunguh dalam beramal sedangkan ilmunya tentang yang dia amalkan tersebut tidak ada, maka usahanya akan siasia. Terkadang usaha yang dilakukan sudah yang terbaik, namun hasilnya tidak sesuai dengan yang diharapkan. Namun ada juga orang yang memiliki ilmu yang banyak, baik dari segi macam teori, namun ilmunya tidak dia amalkan sebagaimana semestinya. Tentu hal tersebut juga termasuk kepada hal yang sia-sia.

Surat Luqman ke-12 menjelaskan bahwa Luqman sudah mendapatkan hikmat mensyukurinya. Dan beliau sudah bisa mengamalkan suatu perbuatan yang sesuai dengan tuntunan ilmunya. " Dan barang siapa yang bersyukur" atas berbagai ragam nikmat dan rahmat yang di berikan oleh Allah, yang tidak terhitung berapa banyaknya, sejak manusia lahir ke dunia sampai dia menjalani hidup, sampai dia dimasukan kembali ke bumi
- "lain tidak, adalah dia yang bersyukur kepada dirinya sendiri". Sebab barang siapa yang mengenang dan menghargai jasa orang lain kepanya dirinya, terhitunglah dia orang yang budiman.

\section{b.Tafsir Al-Mishbah}

Analis tafsir Al-Mishbah Ayat ini menguraikan tentang seseorang bernama Luqman yang di berikan hikmat oleh Allah ta'ala dan beliau juga memberikan nasehat hikmah kepada putranya. Ayat diatas menyatakan: Sungguh Kami Yang Mahaperkasa dan Maha Bijkasana telah megajarkan hikmah kepada Luqman, yaitu: "Bersyukurlah kepada Allah, dan barang siapa yang bersyukur kepada Allah, sesungguhnya ia besyukur untuk dirinya sendiri, dan barang siapa yang kufur,(tidak bersyukur) maka seseungguhnya ia telah merugikan dirinya sendiri. Sedikitpun dia tidak akan merugikan Allah, sebagaimana yang bersyukur itu tidaklah menguntungkan Nya, karena sesungguhnya Allah Mahakaya tidak butuh kepada apapun dan lagi Maha Terpuji oleh seluruh makhluk baik yang di bumi dan maupun di langit.

Dan Kami telah menganugerahkan hikmah kepada Luqman. Kata hikmah disini para ulama mengrmukakan beberapa pendapat terkait makna kata hikmah bahwa hikmah memiliki arti mengetahui dari segala sesuatu, baik itu perbuatan maupun ilmu pengetahuan atau disebut juga sebagai ilmu amaliah dan ilmiah. Ia adalah suatu ilmu yang di dukung oleh amal dan amal. Al-Biqa'i menagatakan seseorang yang ahli di dalam melakuakn sesuatu maka disebut dengan hakim. Hikmah juga diartikan sebagai sesuatu yang bila diperhatikan atau di pergunakan akan menghalangi minim terjadinya mudarat atau kesulitan yang lebih besar dan atau mendatangkan kemaslahatan dan kemudahan yang besar. Makna ini ditari dari kata hakamah yang berarti kendali karena kendali menghalangi hewan atau kendaraan yang akan mengarah kea rah yang tidak di inginkan atau menjadi liar. Meemilih perbuatan yang terbaik 
dan sesuai adalah perwujudan dari hikmah memilih yang terbaik dan sesuai dari dua hal yang buruk pun dinamai hikmah dan pelakunya di sebut dengan hakim (bijaksana).

Abu Hamid Imam Al-Ghazali dalam kitab Ihya Ulumuddin beliau menjelaskan kata hikmah berarti pengetahuan tentang ilmu yang paling utama dan wujud yang paling agung yaitu Allah Swt. jadi hakim disini karena Allah lah yang mengetahui ilmu yang paling abadi. Bentuk fisik sifat maupun zat Nya tidak bisa digambarkan dan tidak bisa pula berubah. Syukur didefenisikan oleh ulama dengan mengfungsikan anugrah yang dietrima sesua dengan tujuan penganugerahkannya. Kata syukur diambil dari kata syakara yang bermakna pujian atas kebaikan secara penuh terhadap apa yang telah diterimanya. Syukur kepada Allah dimulai dari menyadari sesuatu dari lubuk hatinya yang paling dalam betapa besar dan tak terhingganya nikmat yang telah diberikan Allah serta kagum dan tunduk yang akan melahirkan kecintaan yang teramat besar kepada Nya serta dorongan untuk memuji Nya dengan melaksanakan apa yang di perintah kan-Nya

Lalu firman Allah أن اشكر الله an usykur lillah dan Kami katakan kepadanya "Bersyukurlah kepada Allah" makna nya Kami anugerahkan kepadanya syukur. Sayyid Qutub menulis bahwa: "Hikmah, kandungan, dan konsekuensinya adalah syukur kepada Allah Swt. lalu kata يشكر yaskur berbicara tentang kekufuran, digunakan kata kerja masa lampau فر . Penggunaan kata kerja masa lampau pada kekufuran adalah ntuk mengisyaratkan jika itu terjadi meskipun sekali, maka Allah tidak lagi akan menghiraukannya.

Kata غني Ghaniyyun atau Mahakaya diambil dari kata-kata yang terdiri dari huruf غا ghain, ن nun dan ya yang maknanya bekisar pada dua hal yaitu kecukupan, baik menyangkut harta maupun yang lainnya. Imam al-Ghazali mengatakan arti Allah bersifat Ghaniyy adalah Dia yang tidak mempunyai hubungan dengan selain Nya, tidak pada Zat-Nya dan tidak pula pada SifatNya, bahkan Dia Mahasuci. Yang sebenar- benarnya kaya adalah yang tidak butuh حمي د

Hamid/Maha Terpuji diambil dari kata

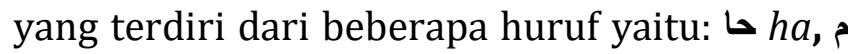
mim, د dal, yang maknanya adalah antonim tercela, kata hamd/pujian digunakan untuk apa uang diperoleh. Ada tiga unsur dalam perbuatan yang harus dimilki oleh pelaku agar apa yang dilakukannya dapat terpuji. Pertama perbuatan yang indah dan baik. Kedua,dilakukan secara sadar dan yang ketiga dilakukan dengan cara tidak terpaksa/dipaksa.

\section{Simpulan}

Pendidikan Aaqidah yang ditanamkan oleh Luqman kepada anaknya yaitu larangan menyekutukan Allah dengan maghlug apapun, karena tiada Tuhan melainkan Allah SWT. Pendidikan syari'ah yang terapkan oleh Luqman kepada anaknya diantaranya: keawajiban dalam menegakkan sholat, kewajiban untuk berbuat amal ma'ruf dan nahi munkar. Dan didalam pendidikan akhlak, Luqman menanam pengajaran kepada anaknya dengan mencontohkan serta mengarahkan anaknya supaya selalu bersyukur kepada Allah SWT dalam setiap keadaan, menjauhkan diri dari sifat sombong dan dengki, berakhlak mulia kepada orang tua, berbicara dengan Bahasa yang sopan dan santun.

Kemudian Luqman mengakhirkan ajaran serta nasehat yang mencangkup intiinti dari tuntunan agama Islam. Yang didalamnya meliputi 3 pokok ajaran Islam yakni Pendidikan aqidah, Pendidikan syariat, dan Pendidikan yang merupakan ajaran pokok yang di jelaskan Allah dalam Q.S Luqman.

Nilai-nila Pendidikan Islam Q.S Luqman Ayat 12-19 Yang Berkaitan Dengan Janji Allah (Al-Wa'du) Menurut Tafsir Al-Azhar Dan AlMishbah.

Kesuksesan Pendidikan berakar dari kandungan nilai pendidikan Islam pada ayatayat dalam surah Luqma, yang memiliki kandungan nilai-nilai pendidikan Islam seperti nilai pendidikan keimanan, nilai pendidikan ibadah, dan nilai pendidikan akhlak serta nilai pengembangan ilmu pengetahuan. Nilai-nilai 
pendidikan Islam yang terkandung dalam surah Luqman itulah yang akan membantu pendidikan Islam dalam mencapai tujuannnya. Nilai-nilai pendidikan Islam dalam Q.S Luqman yan dapat dapat direalisasikan dengan janji Allah Swt (al-wa'du) diantaranya dari ayat 1219, disetiap ayat menjelaskan setiap perbuatan terdapat janji-janji Allah Swt. jika perbuatan yang sesuai dengan pendidikan Islam dilaksnakan denganbaik maka Allah Swt berjanji akan meberikan balasannya di dunia yang berupa kemudahan, kelapangan rezki dan akhirat yang berupa pahala dan syurga.

Nilai-nilai Pendidikan Islam Q.S Luqman Ayat 12-19 Yang Berkaitan Dengan Ancaman Allah (Al-Wa'id) Menurut Tafsir AlAzhar Dan Al-Mishbah Nilai-nilai pendidikan seperti nilai-nilai pendidikan keimanan, nilai pendidikan akhlak dan nilai pendidikan ibadah. Dari delapan ayat surat Luqman ayat 12-19 terdapat di setiap ayat ancman Allah Swt kepada setiap mukmin yang melanggar atau tidak menjalankan nilai-nilai pendidikan Islam. untuk menanggulangi atau melemahkan perilaku negatif, maka ancaman Allah SWT secara tidak langsung merupakan langkah untuk mengaktualisasikan nilai

\section{Daftar Pustaka}

[1] Adi Susilo, Sutarjo. (2012). Pembelajaran Nilai-Karakter: Konstruktivisme dan VCT sebagai Inovasi Pendekatan Pembelajaran Afektif, Jakarta: Rajawali Pers,

[2] Adisusilo,Sutarjo. (2013). Pembelajaran Nilai Karakter, Jakarta: Raja Wali Pers,

[3] Ahmadi Abu dan Salimi,Noor. (2008). Dasar-Dasar Pendidikan Agama Islam, Jakarta: Bumi Aksara,

[4] Al-Ghazali. (2003). Mutiara Ihya' Ulumuddin, Terj. Irwan Kurniawan, Bandung: Mizan,

[5] An Nahlawi, Abdurrahman, Prinsip-Prinsip dan Metode Pendidikan Islam, Bandung: Diponegoro, 1992

[6] Arifmiboy, 'Multiple Intelligences: Mengoptimalkan Kecerdasan Anak Sebagai Upaya Dalam Mempersiapkan Generasi Emas Masa Depan', International Seminar on Education 2016, 2016, 69-84

[7] Anwar, Rosihon. (2008) Ulum Al-Quran, Bandung: Pustaka Setia,
[8] Arief, Armai. (2002) Pengantar Ilmu dan Metodologi Pendidikan Islam, Jakarta: Ciputat Pers,

[9] Arifin,M. (1976) Hubungan Timbal Balik Pendidikan Agama, Jakarta: Bulan Bintang,

[10] Arifin,M. (1976). Hubungan Timbal Balik Pendidikan Agama, Jakarta: Bulan Bintang,

[11] Arifin,M. (1976). Hubungan Timbal Balik Pendidikan Agama, Jakarta: Bulan Bintang,

[12] Aprison Wedra, (2017). Pandangan M Quraish Syihab Tentang Posisi Al-Qur'an Dalam Perkembangan Ilmu, Madania Vol.21,No.2,

[13] Baidan,Nashruddin. (2002) Metode Penafsiran Al-Quran: Kajian Kritis terhadap Ayat-ayat Beredaksi Mirip, Yogyakarta: Pustaka Pelajar,

[14] D. Marimba, Ahmad. (1990). Pengantar Filsafat Pendidikan Islam, Bandung: PT. AlMa'arif

[15] D. Marimba, Ahmad. (1989) Pengantar Filsafat Pendidikan, Bandung: Al Ma'arif

[16] Daradjat, Zakiah. (2011) Ilmu Pendidikan Islam, Jakarta: PT Bumi Aksara,

[17] Drajat,Zakiyah. (1996). Ilmu Pendidikan Islam, Jakarta: Bulan Bintang,

[18] Darul, I. (2014). Mengembangkan karakter Peserta Didik Melalui Kecerdasan Spiritual. Education, 2(2), 53-68.

[19] Harahap,Syahrini. (2000). Metodologi Study dan Penelitian Ilmu-Ilmu Ushuludin, Jakarta: PT Raja Grafindo Persada,

[20] Hasan, M. A., \& Ali, A. M. (2003). Kapita Selekta Pendidikan Agama Islam. Pedoman IImu Jaya.

[21] Madina, S. (2016). Pendidikan Keluarga dalam Surah Ibrahim Ayat 35-41 (Telaah Tafsir Al-Mishbah dan Tafsir Al-Azhar).

[22] Hidayatullah,Syarif. (1998). Metodologi Pengajaran Agama Islam, Jakarta: Proyek Pembinaan Perguruan Tinggi Agama

[23] Jaya,Yahya,( 1994) Spiritualisasi Islam: dalam Menumbuhkan kembangkan Kepribadian dan Kesehatan Mental, Jakarta: Ruhama.

[24] Islam, K., Kehidupan, K. I. D. B. L., Jaya, Y., Sutoyo, A., Kusnawan, A., Maftuhin, A., \& Kalijaga, K. T. U. S. Seminar Nasional, Pelantikan dan Rapat Kerja.

[25] Langgulung,Hasan,( 1988) Pendidikan Islam Menghadapi Abad ke-21, Jakarta: Pustaka Al-Husna,

[26] Langgulung,Hasan, (2004) Manusia Dan Pendidikan Sutu Analisa Psikologi Filsafat 
Dan Pendidikan, Jakarta: Pt. Pustaka AlHusna Baru,

[27] M. Iswantir,( 2019) Pendidikan Islam Sejarah, Peran dan Konstribusi dalam Sistem Pendidikan Nasional Bandar Lampung Aura,

[28] M. Iswantir , A, 'Perspektif Pendidikan Islam', M. Nippan, Abdul, Halim, (2001) Anak Shaleh Dambaan Keluarga, Yogyakarta: Mitra Pustaka, M. Quraish Shihab, Tafsir al-Misbah Volume 10

[29] M. Yusuf, Kadar, (2010) Studi Al-Quran, Jakarta: Amzah,

[30] Minarti,Sri, (2013) Ilmu Pendidikan Islam: Fakta Teoritis-Filosofis dan AplikatifNormatif, Jakarta: Bumi Aksara,

[31] Mujib, (1993) Abdul dan Muhaimin Pemikiran Pendidikan Islam, Bandung: Trigenda Karya,

[32] Mujib, Abdul, (2017). Teori Kepribadian Perspektif Psikologi Islam, Jakarta: Rajawali Pers,

[33] Mujib,Abdul. (2017). Teori Kepribadian Perspektif Psikologi Islam, Jakarta: Rajawali Pers,

[34] Najati, Usman, Muhammad. (2002) Belajar $E Q$ dan $S Q$ dari Sunnah Nabi, Terj. Irfan Salim, Jakarta: Hikmah

[35] Nata,Abudin (1999) Metodologi Studi Islam, Jakarta: Raja Grafindo Persada,

[36] Nizar, (2002) Filsafat Pendidikan Islam: Pendekatan Historis, Teoritis dan Praktis Jakarta: Ciputat Pers,

[37] Nizar, (2002) Samsul Filsafat Pendidikan Islam: Pendekatan historis teoritis dan praktis, Jakarta: Ciputat Press,

[38] Poerbakawatja,oegarda, Ensiklopedi Pendidikan, (, 1981) Jakarta: Gunung Agung

[39] Purwadarminta, (1999) W.J.S. Kamus Umum Bahasa Indonesia, Jakarta: Balai Pustaka,

[40] Qardawi, (2000) Yusuf Merasakan Kehadiran Tuhan, Terj. Jazirotul Islamiah , Yogyakarta: Mitra Pustaka,

[41] Rahmat, Jalaluddin dan Gandaatmaja, Muhtar, (1993) Keluarga Muslim dalam Masyarakaat Modern, Bandung: Remaja Rosda Karya,

[42] Ramayulis dan Nizar, Samsul, (2013) Filsafat Pedidikan Islam, Jakarta: kalam mulia, 2011

[43] Ramayulis, Ilmu Pendidikan Islam, Jakarta: Kalam Mulia,
[44] Roqib, (2009) Moh. Ilmu Pendidikan Islam, Yogyakarta: Lki Printing Cemerlang,

[45] Solahudin M. Agus dan Suyadi,Agus Ulumul Hadis, Bandung: Pustaka Setia,

[46] Sudiyono, (2009) M. Ilmu Pendidikan Islam , Jakarta: Rineka Cipta,

[47] Suma, (2013) Amin Muhammad, Ulumul Quran, Jakarta: Rajawali Pers,

[48] Susilo, Adi , Sutarjo (2012) Pembelajaran Nilai-Karakter: Konstruktivisme dan VCT sebagai Inovasi Pendekatan Pembelajaran Afektif, Jakarta: Rajawali Pers,

[49] Suwito, (2004) Filsafat Pendidikan Akhlak Ibnu Miskawaih, Yogyakarta: Belukar,

[50] Suwito, (2005)Sejarah Sosial Pendidikan Islam, Jakarta: Prenada Media Kencana,

[51] Syafe'i, (2010) Rachmat, Ilmu Ushul Fiqih, Bandung: Pustaka Setia,

[52] Tafsir Ibnu Katsir,

[53] Tafsir, Ahmad ,( 1992) Ilmu Pendidikan dalam perspektif Islam, Bandung: Rosdakarya,

[54] Tasmara,Toto, (2001) Kecerdasan Ruhaniyah Transcendental Intelligence): Membentuk Kepribadian yang Bertanggung Jawab, Profesional, dan Berakhlak, Jakarta: Gema Insani Press,

[55] Thalib,Muhammad, (1996) Pendidikan Islam metode 30 T,Bandung: Irsyad Baitus Salam,

[56] Titus, (1984) Persoalan-persoalan Filsafat, Jakarta: Bulan Bintang,

[57] Uhbiyati, Nur, (2005) Ilmu Pendidikan Islam (IPI) Untuk IAIN, STAIN, dan PTAIS, Bandung: Cv. Pustaka Setia,

[58] Yunus, (1989) Mahmud Kamus ArabIndonesia, Jakarta. PT. Hidakarya Agung,

[59] Yusa'I, Ma'luf, Louis, (1965) Al-Munjid Fi AlLughah wa 'Alam, Beirut: Lebanon, AlKatulikiah, 